\title{
Analysis of Changes in the Utilization of Thermal Water and Geothermal Energy in the North Great Plain Region [Northeastern Hungary]
}

\author{
Kulcsár Balázs ${ }^{\mathrm{A}}$
}

Received: November 2011 | First Revised: February 2012 | Accepted: March 2012

\begin{abstract}
Probably, the most urgent problem of mankind in the $21^{\text {st }}$ century to find a way to satisfy the energy demand of the world's population - having reached seven billion people in 2011 - preferably from renewable sources, by endeavouring to apply environmentally sparing methods. From Hungary's perspective, it is a goal of priority significance, as it is an area that is not abound in fossil energy resources, and thus becoming increasingly exposed to the energy policies of the producer countries. If Hungary, which has favourable endowments in the field of renewable energy resources, lays larger emphasis on the application and processing of environmental industry technologies, the economic vulnerability of the country can be mitigated.

This study discusses the distribution of the utilization of geothermal energy and its carrying medium, thermal water among the sectors of the economy, as well as its changes over time, the utilization potentials of alternative energies in the northeastern region of Hungary. This region has outstanding facilities in the field of thermal water and geothermal energy resources, yet their utilization rate - with respect to the available thermal water capacities - is rather low. It is a consequence of the regulatory requirements posed on operators, high investment and maintenance costs, the general shortage of resources, the difficult situation of the industries and municipalities, as well as the fact that the solid and liquid media of energy storage lying at depths of thousands of meters, the methods and potentials of exploitations, their sustainability are not or are just partly known.
\end{abstract}

Key words: Northeastern Hungary, North Great Plain Region, thermal water, geothermal energy, renewable energies, environment industry

\section{Introduction}

The focal point of this study is the analysis of the northeastern part of Hungary in terms of economic geography, from the perspective of trends in the utilization of thermal waters and geothermal energy. The area of the study is the North Great Plain Region, i.e. Hungary's northeastern region of statistical planning, which encompasses three counties: Szabolcs-Szatmár-Bereg, Hajdú-Bihar and Jász-Nagykun-Szolnok. The studies have investigated the extent of the utilization of geothermal energies, the fields of economy and public administration that are covered by their use. They have further wanted to find out for the satisfaction of what economic demands thermal wells were originally established in the region, how the goals of operation changed in the course of operation, and how the sectoral distribution of the utilization of the wells looked like in 2orr. The number of the wells that are currently out of use as a result of the termination, dissolution of the earlier operator-consumer has also been established. These investigations have relied on quantitative and deductive methods, including the analysis and processing of the data and information that are available at the regional directorates of water management, and besides empirical studies have been performed in the course of which the associated statistical figures have been updated. 
Due to the northeastern-southwestern orientation of the examined area of favourable geothermal endowments, considerable differences have been found in terms of the exploitable temperatures. Most of the thermal waters in the region are stored in Upper Pannonian layers, which grow gradually thicker from the feet of the enclosing mountains towards the inner areas of the basin, and tend to lie at increasing depths (Molnár, I984). Accordingly, from the northeast to the southwest thermal water endowments tend to improve gradually, the temperature of water that is available for exploitation increases, while on the other hand the use of thermal water and the dominance of the individual areas of use are somewhat in conflict with the opportunities bettering to the southwest.

The geothermal endowments of the area of the North Great Plain Region can be considered to be favourable even in global comparison (Stegana et al., 1975), which - owing to the just $20-25 \mathrm{~km}$ thick subgrade of the basin (Molnár, I984), the porous thermal water-yielding layers up to the thickness of I,500 meters, the cracked and karstic thermal water storage systems under them down to depths of $4000-4500$ meters and $4.5^{\circ} \mathrm{C} / \mathrm{Io0} \mathrm{m}$ geothermal gradients -, results in a $60 \mathrm{PJ} /$ year geothermal potential (Mádlné, 2008), 90-Ioo mW/sq $\mathrm{m}$ heat flow (Royden et al., I983; Royden, Dövényi, I988), $35-130^{\circ} \mathrm{C}$ temperature values at depths of 500-2000 meters, as well as water yields of Io-Ioo $\mathrm{cc} \mathrm{m} / \mathrm{h}$ (Dövényi et al., 200I). The majority of the thermal water under the territory of Hungary is of low enthalpy, and therefore their use would allow heat and water utilization at the current state of technology. Waters of the highest temperatures feature $80-90^{\circ} \mathrm{C}$, which in communal utility supply would be suitable for satisfying the demands of heating, sanitary hot water, air-conditioning and drinking water supply. Concerning the economic sectors, it can be used in tourism, industry and a broad range of agricultural activities. The most dynamically developing area is balneology, the water supply of bathing places. This tendency is true for both Hungary and the North Great Plain Region. The reason underlying the dynamic development of this method of utilization can be traced back in the priority role of health and adventure tourism in the country's tourism concept, as well as the associated earmarked grants (Csomós, Kulcsár, 20II). With respect to the heating of buildings, this solution can be applied efficiently in settlements where the population lives in a concentrated structure. The increasing energy prices, the financing problems that local governments face, as well as our energy dependence gradually set alternative heat service solutions to top priorities.

\section{Sectoral and territorial changes in the utilization of geothermal energy and thermal water}

In the county, all the thermal water wells have been established in the Upper Pannonian sand and sandstone layers. In the Bereg Region bordering on the Northeastern Carpathians and in the surroundings of Nyírlugos, the high-lying Upper Pannonian layers do not bear thermal waters. In comparison with the other areas of the Great Plain, the properties of this region in terms of the hydrogeology of thermal waters are less favourable. From the thermal water reservoirs of the Upper Pannonian layers, thermal waters up to $67^{\circ} \mathrm{C}$ have been explored in the vicinity of Tiszavasvári, whereas the high-lying, also Upper Pannonian formations around Nyírlugos yields subsurface water of less than $30^{\circ} \mathrm{C}$ (Lorberer, 2009).

In the county, the first wells were established in 1958, in Nyíregyháza and Kemecse. The largest number of drillings was made in the 1960s, and therefore - they have been in use for over 40 years. With respect to the construction of the wells, until the ig8os a decreasing tendency could be observed, and then it gathered new impetus in the I990s and after 2000. Today, the oldest wells can be found in the surroundings of Ibrány-Nagyhalászi, as well as in Nyíregyháza and NyíregyházaSóstófürdő.

Seventeen settlements of the county have altogether 34 thermal wells, and with respect to their utilization at the time of their establishment three main areas - bathing, medical and industrial use - can be distinguished. In addition to balneology, the Upper Pannonian reservoir was also utilized in a subordinated manner, for communal water supply, industrial and agricultural purposes, yet the dominant way of use was the mostly seasonal bathing utilization and drinking water supply. Use for energetic purposes may be implemented primarily in agriculture, for the heating of stables and other buildings.

In view of the hydrogeology of thermal waters, the endowments of Hajdú-Bihar County more or less correspond to the average of the Great Plain with the eastern districts being less favourable; from the Upper Pannonian measures, no thermal waters over the temperature of $85^{\circ} \mathrm{C}$ can be anticipated to be explored. The local thermal wells have been constructed as filtered through porous Upper Pannonian - and sometimes younger Upper Pleistocene and Lower Pleistocene layers (Lorberer, 2003.). In Hajdú-Bihar County, the first exploratory drilling for thermal water had been performed in I9I5 in Balmazújváros, and until the I950s a relatively small number (I6) of drillings with effluent water over $30^{\circ} \mathrm{C}$ were turned 
into wells. Most of the thermal wells in the region were drilled from the I950s to the I980s, and then the recession of the I99os set this impetus back. A new impetus was given by the considerable supports and grants furnished to the development of bathing facilities after 2000 , and since then eight such facilities have been opened, and thus the county now has 94 wells in 3I settlements. The thermal wells located in Hajdú-Bihar County can still be regarded to be rather young. The most recently constructed facilities are the wells in the microregions of Hajdúszoboszló, Debrecen, Hajdúböszörmény - 17-26 years have elapsed since their establishment -, which is due to the relatively large number of wells constructed after the turn of the millennium. The oldest wells can be found in the region of Berettyóúffalu. The thermal well boasting of the highest effluent temperature is operated in Hajdúszoboszló, where thermal water of $78^{\circ} \mathrm{C}$ is brought to the surface from a depth of I,62I meters. In Hajdú-Bihar County, utilization is almost fully subordinated to use in bathing establishments. The exploited temperatures have geothermal capacity reserves that have just partly been utilized.

In the North Great Plain Region, Jász-NagykunSzolnok County has the largest number of thermal water wells. Most of the drillings made in this area can be found in the Jászság region and the surroundings of Szolnok. In the center of the Pannonian Basin, the sediment sequence are of considerable thickness, yet in certain areas of the county - such as in the Jászság region - the large number of wells are settled on the rather poor water-yielding capacities of shallower layers, and therefore in these areas a large proportion of thermal water use services communal drinking water supply.

Most of the thermal wells were constructed in the I960s and I970s, while the subsequent 30 years saw a decreasing number of well drilling. Quite surprisingly, in this period the largest number of thermal wells were built or reconstructed with new drillings in the recession-laden I990s.

The large majority of those wells in JászNagykun-Szolnok County that feature effluent water over $30^{\circ} \mathrm{C}$ have been built with reliance on the water well drilling technology, particularly for the withdrawal of water. Similarly, the largest number of unused hydrocarbon drillings has been converted into thermal wells in Szolnok, and besides such wells have been established in Szandaszőlős, Kengyel, Tiszaörs and Karcag. There are several thermal wells operated in the country that are used as depth monitoring wells in addition economic purposes, with the exception of the drilling of Jászladány, that solely serves the former end. In view of the effluent temper- ature of the thermal wells, the hottest wells are situated at the edge of the Békés Depression, as well as by River Tisza, with a considerable proportion of them being thermal wells converted from unused hydrocarbon drillings; the highest effluent temperature belongs to the three drillings in Cserkeszőlő - the temperature of the thermal water here is $83^{\circ} \mathrm{C}$ on the surface, and reaches up to $143^{\circ} \mathrm{C}$ at a depth of $231 \mathrm{I}$ meters -, and a well in Túrkeve whose temperature is over $80^{\circ} \mathrm{C}$. The effluent temperature is higher than $70^{\circ} \mathrm{C}$ in the case of a well in Karcag, Tiszaföldvár, Törökszentmiklós, Túrkeve, and two thermal wells in Mezőtúr. Besides, in 8 settlements there are altogether 13 thermal wells that yield waters of 60 $70^{\circ} \mathrm{C}$. The majority of them follow the course of River Tisza.

In Jász-Nagykun-Szolnok County, I77 wells have been drilled in 43 settlements. From among the 7 statistical microregions of the county, the largest number of thermal wells can be found in Jászság (54), and the Szolnok area (43), which also form the surroundings of most of the settlements that have thermal wells. Szolnok has the largest number, i.e. 2I wells, followed by Jászkisér and Jászapáti both with $\mathrm{I} 2$ wells.

In consequence of its favourable endowments, i.e. layer measures of good water-yielding capacities, Jász-Nagykun-Szolnok County has a large number of wells, and makes the use of water for communal purposes to be dominant, but these wells serve only reserve water supply purposes, and show significance just in certain areas. Most of the operating wells satisfy the demands of agriculture and bathing facilities. At the present, thermal waters are just scarcely used for heating, but its volume could be increased by deploying unutilized wells - the largest number of such wells can be found in this region - for production, as well as the multiphase use of the operating wells. The operation, reconstruction of existing, but currently not utilized, closed thermal wells, and the establishment of new wells could satisfy broad-scaling user demands.

Hereunder, the roles and shares of the individual economic sectors are examined in connection with the utilization of geothermal energy and thermal water in the North Great Plain Region, as well as changes having occurred in these areas, with a highlight on the available, but unutilized capacities.

\section{Utilization for bathing purposes}

The primary field of utilization for thermal water production in Hungary includes bathing and swimming establishment services, as well as the associated balneological and therapeutic use. It is also characteristic of the North Great Plain Re- 
gion, where in Szabolcs-Szatmár-Bereg and Hajdú-Bihar County the use these resources in thermal water baths clearly stands out against other fields of utilization, while the Jász-Nagykun-Szolnok County other areas are prioritized. In Szabolcs-Szatmár-Bereg County, $70 \%$ of the wells have been established for bathing and swimming establishment services, and nearly half of the thermal waters used are qualified as medicinal waters. Most of the bathing facilities are operated on a seasonal basis, and are to satisfy the demands of the local population, like the bathing establishments of Máriapócs, Nagykálló and Vásárosnamény. Complexes of regional significance can be found in Nyíregyháza and NyíregyházaSóstófürdő, where the new and winterized buildings provide bathing services all round the year. The peak volume of thermal water production for bathing purposes was recorded in 1994, and in the following year thermal water utilization dropped by $30 \%$ (Lorberer, 2009). According to the 20II survey, the utilization profile is more or less the same as at the time of establishment, yet by today $2 \mathrm{I} \%$ of the wells have been de-commissioned or closed down. Wells formerly used for bathing purposes have been mostly closed down due to the dissolution of agricultural plans and industrial companies having operated the thermal wells, as well as the shortage of resources on the side of the local governments. In comparison with the other sectors, the termination of these wells - basically, with respect to the large number of such establishments - has been less perceivable, the corresponding rate has changed from $70 \%$ to $64 \%$ in the county.

Owing to Hajdúszoboszló and Debrecen, Hajdú-Bihar County is a natural scene for the balneological utilization of the Upper-Pannonian thermal water reservoirs, and the area for the establishment of most of the wells concerned. This region boasts of the largest number, i.e. I4 thermal water wells qualified to be sources of medicinal waters. Beside the Upper Pannonian measures, only wells filtering across Upper-Pliocene

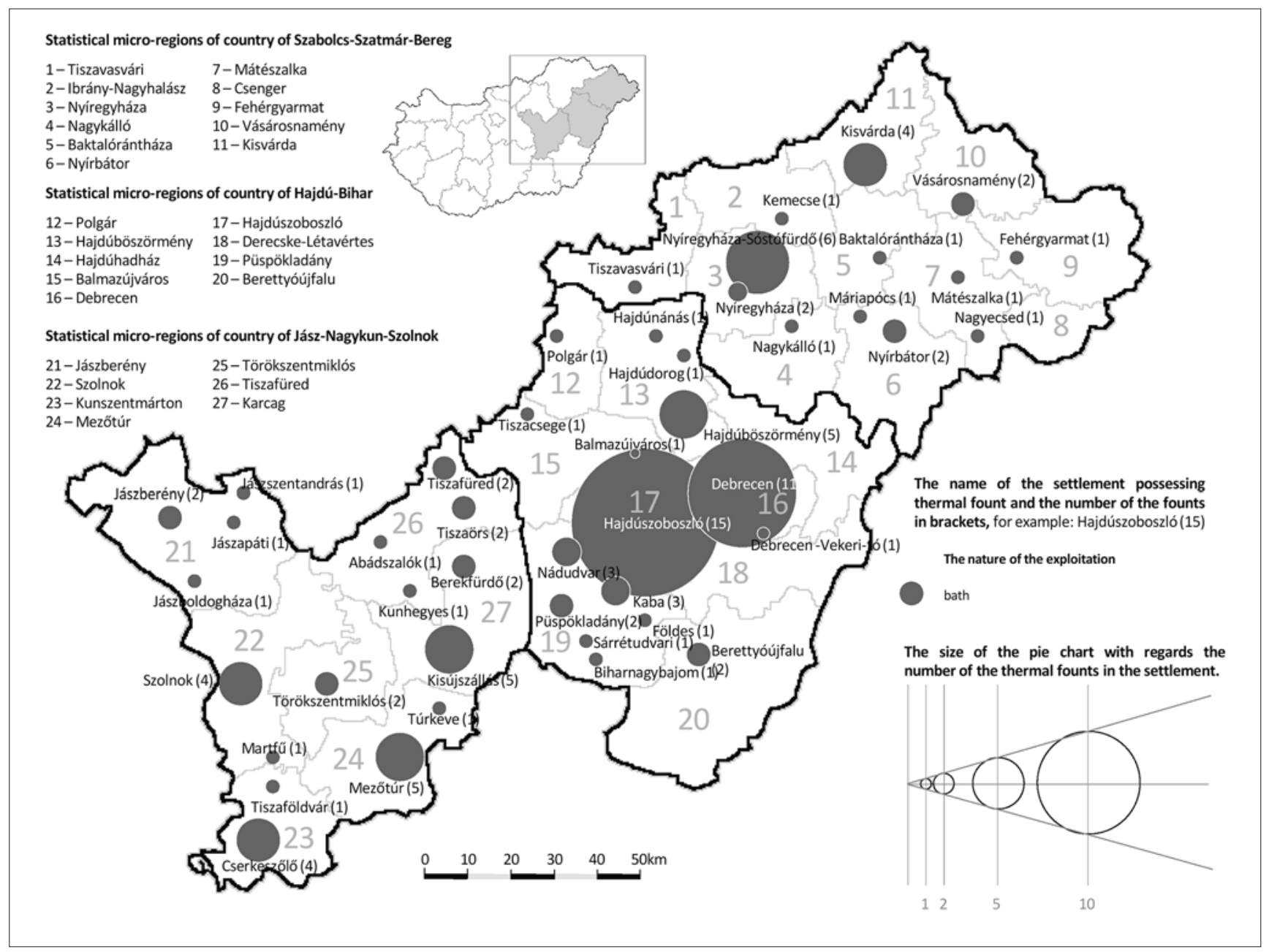

Figure 1. Territorial distribution of thermal wells constructed in the North Great Plain Region for bathing and swimming establishment services [Source: figure created by the author based on data of Upper-Tisza Region Environmental and Water Directorate, Trans Tisza Region Environmental and Water Directorate, Middle-Tisza Region Environmental and Water Directorate and the author] 


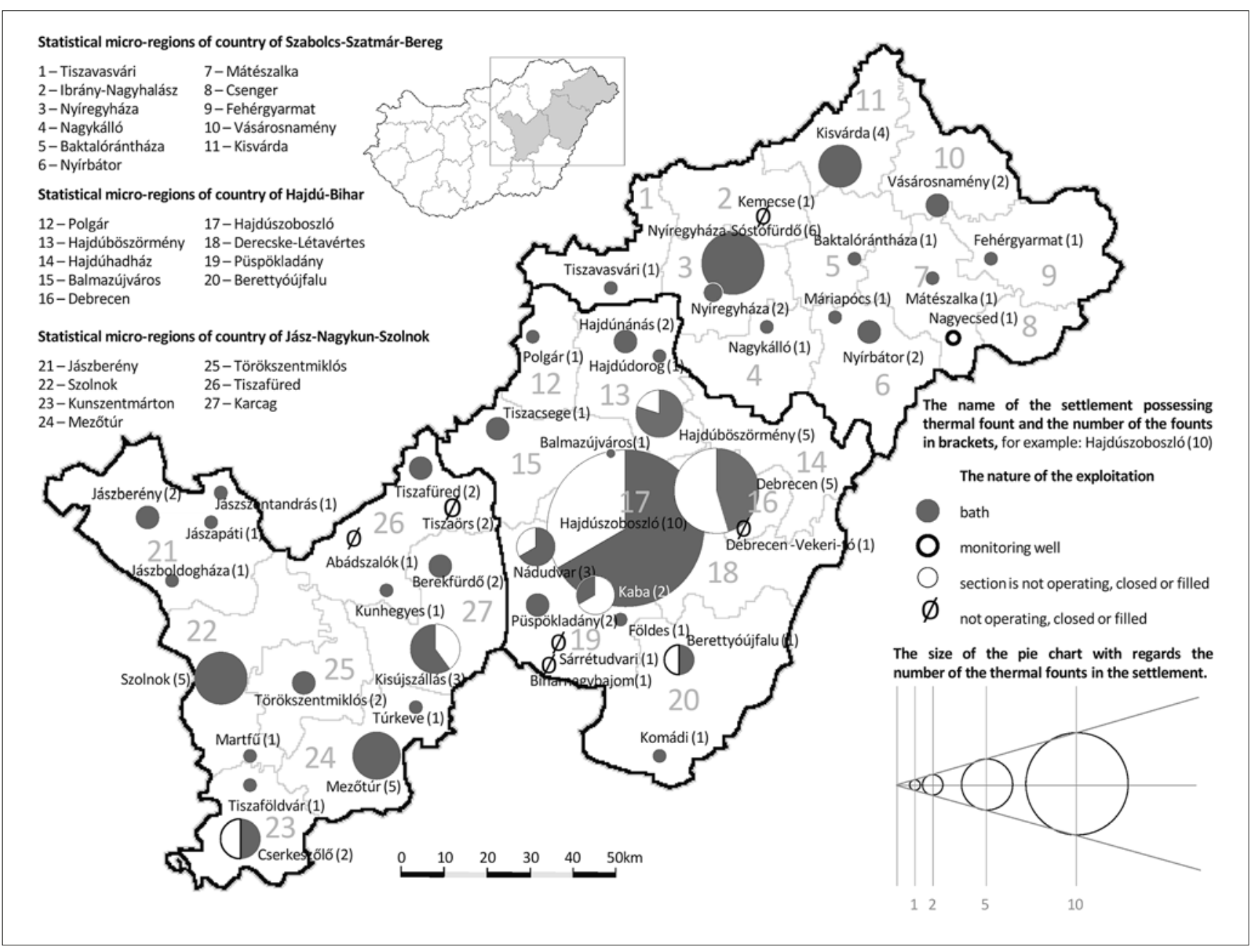

Figure 2. Utilization of thermal wells constructed in the North Great Plain Region for bathing and swimming establishment services, in 2011 [Source: collected by the author from owners of thermal wells]

(Komádi) and Lower Pleistocene (Berettyóújfalu) layers have been utilized for bathing purposes, while in the area neighbouring on Békés County several wells have been constructed for water supply. Hajdúszoboszló and Debrecen both have a large number of wells, but as a result of intensive exploitation the descending stationary and operating water levels have forced operators to designate protective zones of considerable expanses, which means that no further drillings may be made in the other settlements of the region. In view of the utilization of thermal wells, the supply of bathing facilities has been dominant with $52 \%$. In the period from the establishment of wells until 20II, the most significant change in thermal water utilization has been seen in this county, the overall structure of utilization has been considerably transformed. Bathing and swimming establishment services have continued to be the dominant form of utilization with $33 \%$, yet this field has witnessed remarkable improvement with respect to multistage utilization, i.e. more than half of the waters coming from the bathing facilities (Debrecen, Hajdúszoboszló, Hajdúböszörmény, Ber- ettyóújfalu, Hajdúnánás and Tiszacsege) have already been used as a source of geothermal energy.

However, geothermal heating is mostly restricted to the buildings of the bathing establishments and in some places to the connected catering units. Within the North Great Plain Region, in 20II this county has been the area with the largest number of thermal wells out of use - their proportion is $37 \%$-, with most of them being serviceable wells that are closed or not operated, while 9 wells have been terminated, filled up. Nearly all the sectors have suffered substantial decrease, but as a result of the large number of wells utilized for bathing purposes this considerable drop - by I9 wells - has not been very remarkable, still represented a significant 36\%. In 20II, the largest users of thermal water were the municipal baths, as well as bathing complexes of national and international significance. Most of these facilities have been winterized in the past two decades, and expanded with a large number of additional buildings. Thus, Hajdú-Bihar County has retained balneological use, and further increased its dominance in the field of utilization (Figure I-2). 
The fields of use of the water coming from the thermal wells of Jász-Nagykun-Szolnok County are more versatile in comparison with the two other counties of the region. $20 \%$ of the wells have been constructed for the supply of bathing establishments that - similarly to the northern county of the region - mostly serve the demands of the local population. High-standard services and the volumes of thermal water utilized make Szolnok, Mezőtúr and Kisújszállás special scenes of use, and Berekfürdő is also widely known. In Jász-Nagykun-Szolnok County - with the exception of balneological utilization serving as the basis of medicinal and wellness tourism -, the sectors consuming large volumes of thermal water have been hit by a general drop of thermal water use. When the three counties are compared, this is the county where the largest number of production wells has been closed down. In the field of bathing and swimming establishment services, a 20 fallback has been experienced, and therefore the county currently represents $16 \%$ of the county's thermal water utilization. With respect to the operated thermal wells, most of the wells are currently operated for communal water supply, bathing and swimming establishment services, as well as agricultural demands (Figure I-2).

\section{Utilization for agricultural purposes}

In Szabolcs-Szatmár-Bereg County, the utilization of thermal water for agricultural purposes is less preferred, with the underlying reason being weak endowments. For agricultural use, the largest portion of the area of the county cannot be regarded to be promising, because the water yields and capacities of the wells that can be operated only with the application of submergible pumps are rather limited (Lorberer, 2003). An exception was the thermal well of Gemzse, where the local agricultural cooperative opted for this technology to heat its vegetable tents and greenhouse, and therefore they were the only ones in the country to utilize geothermal energy in this manner. According to the 2orr survey, the agricultural-geothermal system operated in Gemzse was de-commissioned due to the dissolution of the agricultural cooperative, and therefore the only well used dedicatedly for the generation of heat energy is now unutilized. In the future, these thermal waters featuring lower temperature ranges than in the other areas of the region can have a role in agriculture, particularly in heating stables, as the exploitable water temperatures are the most suitable for heat regulation in buildings. In view of the resumption of use, the closed wells that can be found in the county are virtually in such desolate conditions that in most cases they cannot be profitably reconstructed in comparison with the costs of the establishment of new pairs of wells (Figure 3-4).

In Hajdú-Bihar County, use for agricultural purposes has always been of a narrower scale (Lorberer, 2003), and this tendency has not changed by today. Beside the Upper Pannonian measures, wells filtering across Upper-Pliocene (Komádi) and Lower Pleistocene (Berettyóújfalu) layers have been established in a large number, in the area neighbouring on Békés County, primarily for satisfying the demands of small settlements and agricultural plants for water supply. Wells with effluent temperatures over $30^{\circ} \mathrm{C}$ were used both for agricultural purposes and in communal waterworks. I5\% of the county's 94 thermal wells served specifically agricultural goals, and another $9 \%$ were used for agricultural functions alongside bathing and swimming establishment services. Examining changes in the utilization of thermal water from the establishment of wells until 20II, one would claim that the most substantial change could be seen in this county. It is still the bathing and swimming establishment services that remained dominant with $33 \%$, but only $2 \%$ belong to the joint operation of bathing facilities and agricultural use that was formerly very much characteristic of Hajdú-Bihar. Within the scope of thermal water consumption, agriculture has a still considerable share with $9 \%$, with its typical area lying in the south of the county. Due to the decline of rural areas and peripheries near the border, the dissolution of agricultural plants operated in small settlements meant the end of the utilization of thermal water for agricultural purposes. Nearly all the sectors have suffered considerable fallback, but the actual extent of decrease has come to be the second largest in the case of agricultural utilization. Unfortunately, most of them - due to their location in outer areas - have not been given new functions as a result of the changed economic structure. In most of the wells established in larger settlements for agricultural and balneological purposes, the agricultural function has been terminated, or become bankrupted, while the released capacities have been used for bathing developments and the heating of the connected buildings (Figure 3-4).

The fields of the application of the water exploited from the thermal wells of Jász-NagykunSzolnok County can be said to be more versatile in comparison with the other two counties. The main water supply is followed by wells for agricultural purposes with $27 \%$; in this category, water use for animal farming and thermal wells serving other agricultural functions can be clearly distinguished, and their ratio is 15 to $85 \%$. The Jászság area can be characterized by the broad-scaling utilization of thermal water for agricultural pur- 


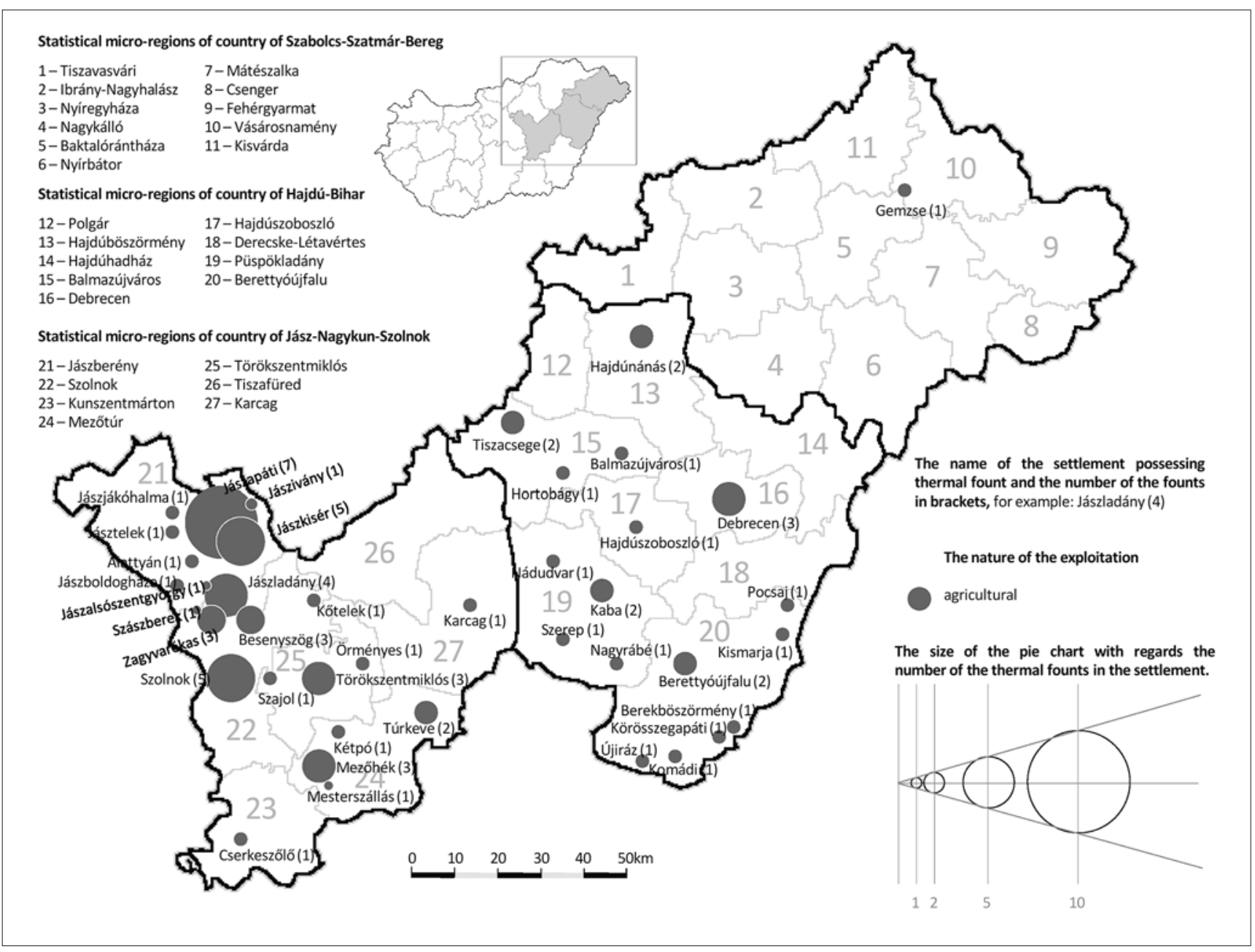

Figure 3. Geographic locations of thermal wells established in the North Great Plain Region for agricultural purposes [Source: figure created by the author based on data of Upper-Tisza Region Environmental and Water Directorate, Trans Tisza Region Environmental and Water Directorate, Middle-Tisza Region Environmental and Water Directorate and the author]

poses, and these wells have been specifically established for the water supply of animal farms, as well as irrigation, greenhouse heating, as well as sanitary use. The 2oII survey suggested the drastic fallback of large-scale plant farming and animal breeding, and in this context 15 wells were withdrawn from production, therefore the number of wells having agricultural functions decreased to $18.5 \%$. The nearly $32 \%$ drop - similarly to Hajdú-Bihar - was caused by the dissolution of cooperatives and state-owned farms. These capacities are still available, yet are mostly in unkempt conditions due to the ignorance of the necessary scheduled maintenance and developments.

Another obstacle to the increased utilization of geothermal energy and thermal water is that among enterprises involved in animal breeding the current processes favour the investment of resources in the generation of biogas, as they are to comply with the rules on the handling of liquid manure (Ministry of National Development, (2009), Decree 59/2008 (Apr 29) of the Ministry of Agriculture and Rural Development, Decree
27/2007 (Apr 17) of the Ministry of Agriculture and Rural Development). As a consequence, the available thermal water potentials continue to serve the performance of the well-established tasks, while utilization for energy purposes is not anticipated even in the medium-term plans (Fig. 3 \& 4.).

\section{Utilization of thermal water and geothermal energy for industrial purposes}

For use in industry and food processing - covering altogether $15 \%$ of the thermal water wells established in the county -, thermal wells have been established in six plants: to serve the bottling plant of Várda Drink Alcohol Manufacturing Company in Kisvárda, the hemp factory of Nagyhalászi and the tobacco fermentation plant of Nyíregyháza. The newly established well of Cégénydányád was also built for the purpose of mineral water bottling in 2008. According to the 20II survey, the utilization profile more or less corresponds to the distribution upon the establishment of the wells, but by today $60 \%$ of the wells have been de-commissioned or closed down. When these chang- 


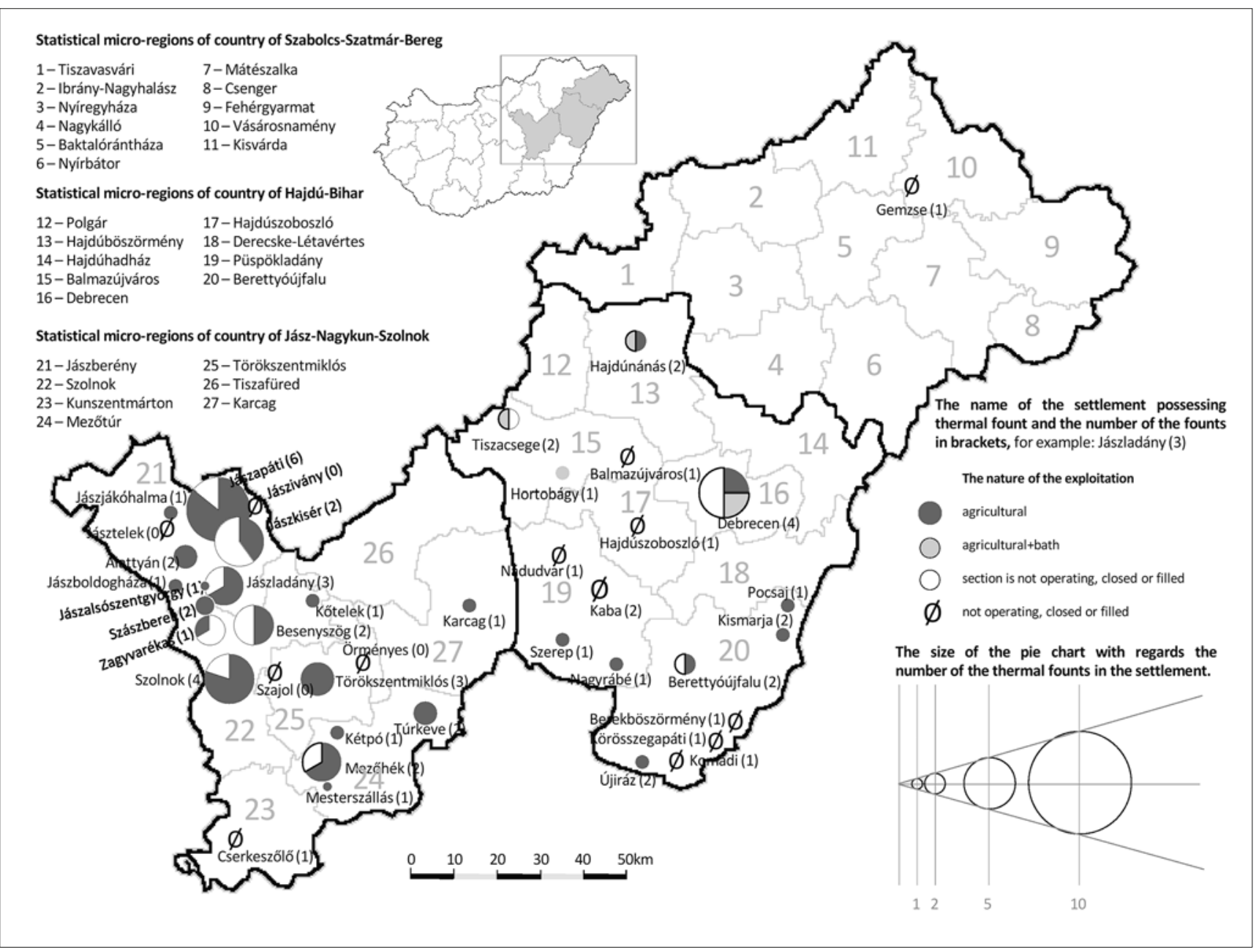

Figure 4. Utilization of thermal wells constructed in the North Great Plain Region for agricultural purposes, in 2011 [Source: collected by the author from owners of thermal wells]

es are examined in a geographic context, most of the wells that are out of operation or have been terminated can be found in the region of IbrányNagyhalászi and Kisvárda as a result of the process strongly affecting industry. The diminishing functions of the thermal wells as conceived at the time of their construction have been due to mainly the termination of the industrial companies operating the former thermal wells. No water is produced from the wells of the former hemp factory of Nagyhalászi, and so far the Local Government of Nagyhalászi having taken the wells over has not been able to find a new operator. Constructed in 1994 for the bottling of mineral waters, the well of Várda Drink in Kisvárda has not been commissioned due to the subsequent reduction of the product range, and similarly the well built in Csengersima in I99I has not been in operation since its establishment. On the basis of the above tendency, by today the ratio of thermal wells used for industrial purposes has decreased to $6 \%$. Water is taken in the mineral water bottling plant of Cégénydányád and the tobacco fermentation facility of Nyíregyháza, though in this latter pant
$65 \%$ of the extracted thermal water is used as sanitary hot water, and just $35 \%$ is consumed as industrial-technological water (Fig. 5 \& 6).

In Hajdú-Bihar, six wells used to serve industrial objectives, one of which in Debrecen was designed for multistage, industrial and balneological utilization. There is a considerable number of wells here whose water was originally planned to be consumed to satisfy solely industrial demands - principally in food processing and light industry.

When looking at thermal water use from the establishment of the wells until today, the most significant change has been seen in this county. Within the North Great Plain Region, in 2011 it was the county where the largest number of thermal wells out of operation could be found. Substantial fallback has been suffered by all the sectors, but in terms of percentages the largest loss belongs to industry. Due to the close-down of the facilities in Debrecen, Berettyóújfalu and Komádi, $66 \%$ of the thermal wells drilled for industrial purposes are currently not utilized. The leather factory of Debrecen was dissolved in the second half of i990, while the meat-processing plant was 


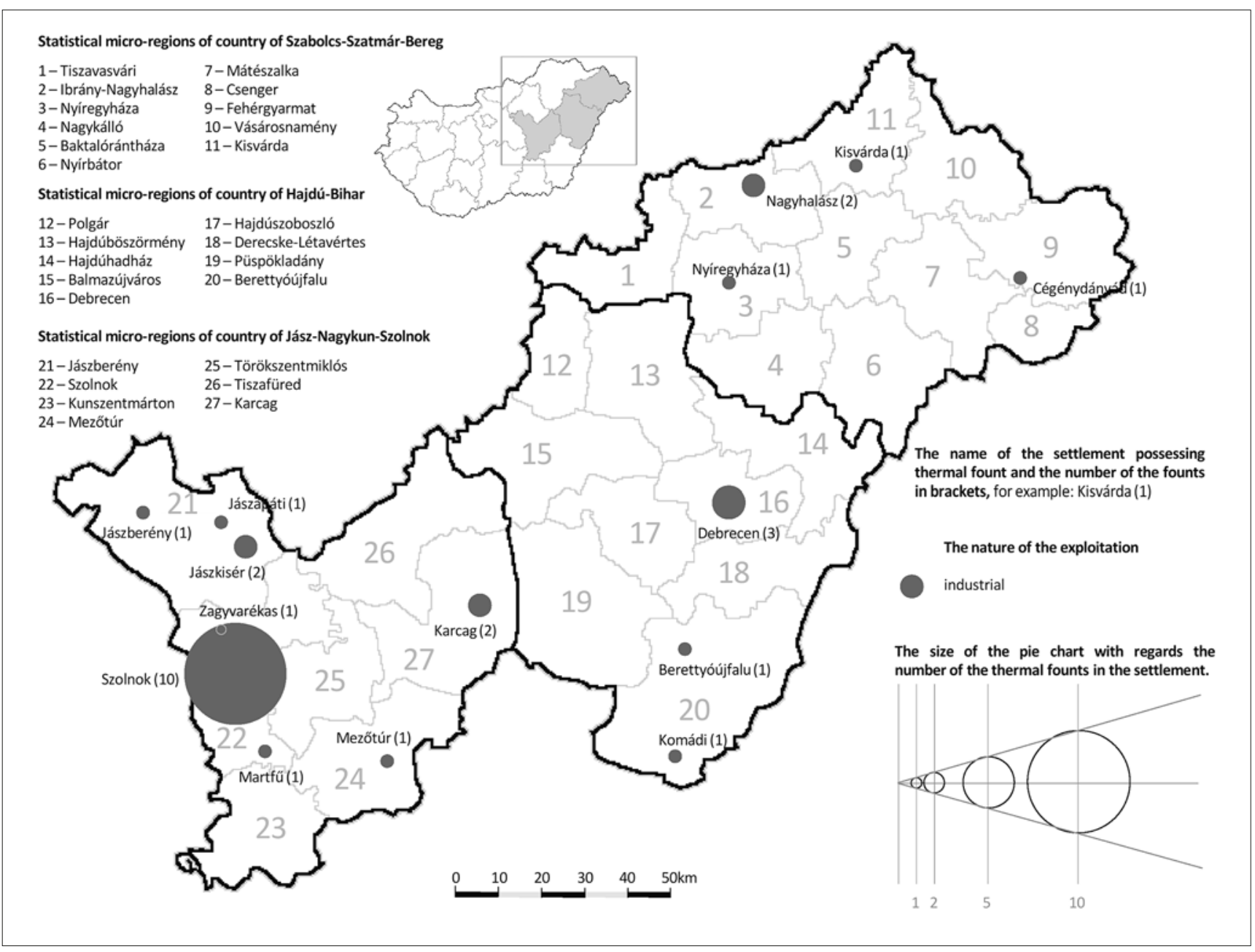

Figure 5. Thermal water wells constructed in the North Great Plain Region for the performance of industrial tasks [Source: figure created by the author based on data of Upper-Tisza Region Environmental and Water Directorate, Trans Tisza Region Environmental and Water Directorate, Middle-Tisza Region Environmental and Water Directorate and the author]

closed down in the summer of 20II, yet its thermal well has been out of use since 2008. In Komádi, it was the hemp factory that used thermal water, but it is not operated any longer. Nowadays, from among the wells drilled for industrial purposes the well used by the Iron Industry Company (Elzett) in Berettyóújfalu and the well utilized for complex industrial and bathing purposes in Debrecen are in production, and therefore the ratio of operating industrial wells in the county has shrunk to $2 \%$ (Figure 5-6).

In view of the fields of the application of water exploited from the thermal wells of JászNagykun-Szolnok County, a considerable proportion, i.e. II\% was given by industrial utilization, yet it was shared by a relatively large number of sub-sectors. Within the North Great Plain Region, this area shows the highest rate of thermal water utilization for industrial purposes. Most of the 20 industrial thermal wells have been established in Szolnok, Martfü, Mezőtúr, Zagyvarékas, Jászberény and Jászkisér. With respect to the subsectors concerned, particularly the water de- mands of food processing have been satisfied from these water resources, such as the sugar mill of Szolnok. In terms of volumes, food industry is followed by the thermal wells serving mechanical engineering and public transport companies, the bus and coach depot, the railway station and sports grounds of the Hungarian State Railways (MÁV). In Jászság, the largest thermal water consumers are the Lehel Refrigerator Factory of Jászberény and the Construction Machinery Service Workshop of MÁV. In the field of light industry, the Tisza Footwear Factory of Martfü, while in chemical industry the Chemical Works of Szolnok and the petrochemical company founded for MÁV should be mentioned, where thermal water is used in the form of energy, and additional thermal wells were constructed in 2009 to serve the Industrial Park of Szolnok.

The industrial production of the county has fallen victim to the new economic regime. After the closing of the wells having been used by the dissolved companies, the number of thermal wells serving industrial purposes has dropped by 


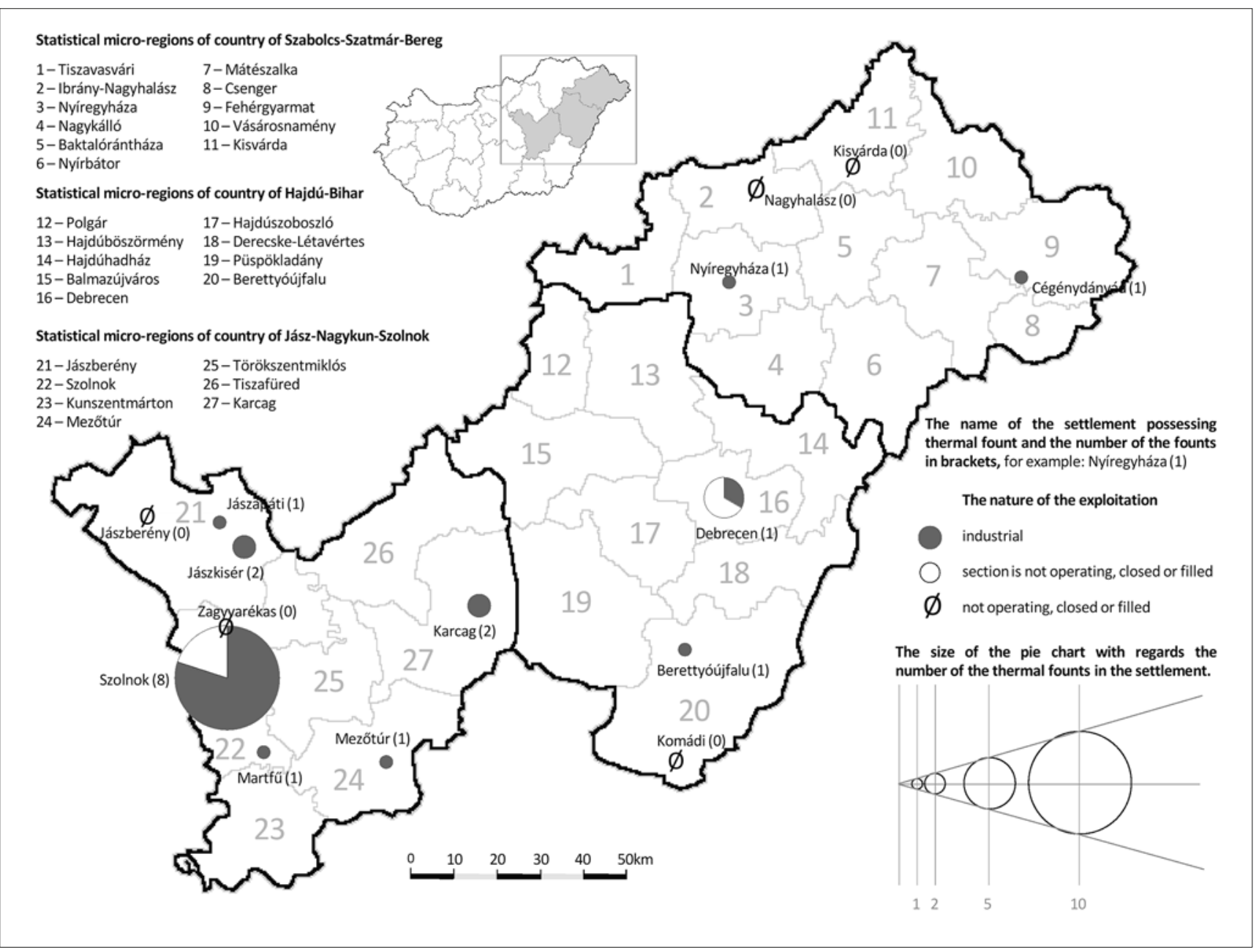

Figure 6. Utilization of thermal wells constructed in the North Great Plain Region for industrial purposes, in 2011 [Source: collected by the author from owners of thermal wells]

40\%. The largest number of wells have discontinued their production operations in Szolnok, while in Jászberény and Zagyvarékas the industrial utilization of thermal water has been fully terminated. In most of the medium-sized settlements - in Jászapáti, Jászkisér, Martfü, Mezőtúr and Karcag -, smaller industrial plants still operate their thermal water wells, and as a result the ratio of industrial thermal water utilization in the county is $7 \%$ today (Figure 5-6).

\section{Communal and multistage utilization}

In the service sector of Szabolcs-Szatmár-Bereg County - with the exception of tourism and local bathing services -, the medical utilization of thermal water is characteristic of three settlements, Nyíregyháza, Nyíregyháza-Sóstófürdő and Fehérgyarmat, and therefore this type of use has $9 \%$ in overall utilization. $32 \%$ of the thermal wells are used in a multiphase and shared manner where bathing, medical and industrial functions are all included in the scope of communal water supply.

According to the 2oII survey, the field of medicine can be characterized by a $3 \%$ fallback, though the underlying reason has been the replacement of the well in the process of the extension of Jósa András Hospital of Nyíregyháza, and therefore in this respect just a relative decrease can be recorded. In Nagyecsed, the function of the well formerly used for filling the pools at the bathing establishment has been transformed, and today it is applied as a monitoring well. (Figure 7-Io).

In Hajdú-Bihar County, with respect to the purposes of establishment bathing facilities were followed by the thermal wells constructed for drinking water supply and now representing $22 \%$. One-tenth of the wells have been designed for combined use. In line with the existing heat and water demands, the water of eight wells has been dedicated to multiphase bathing and agricultural use, a well in Balmazújváros has been constructed for bathing purposes and communal water supply, whereas a well in Debrecen serves industry and bathing alike. A significant 5\% is represented by the depth monitoring wells of the Geological Institute of Hungary (MÁFI), and the underlying 5 wells do represent a large number in comparison with the other two counties. 


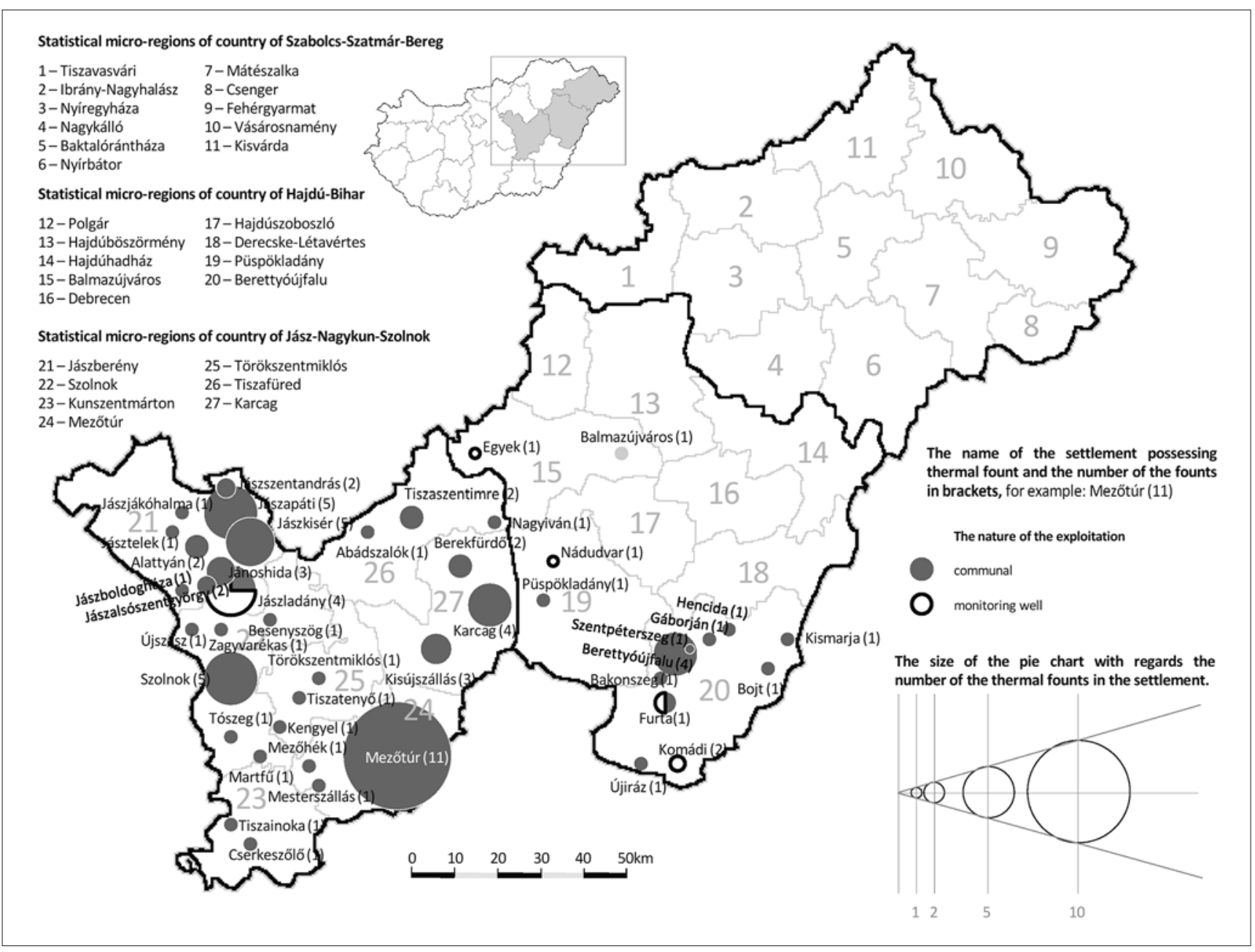

Figure 7. Thermal water wells constructed in the North Great Plain Region to serve communal and water supply functions [Source: figure created by the author based on data of Upper-Tisza Region Environmental and Water Directorate, Trans Tisza Region Environmental and Water Directorate, Middle-Tisza Region Environmental and Water Directorate and the author]

By 20II, multistage utilization has undergone notable improvement with respect to the abovementioned bathing complexes, and thus in the future beside balneological utilization the heat energy of thermal water will not be lost either. Geothermal heating is mostly restricted to the buildings of the bathing facilities, catering units in some locations, with the exception of one of the thermal wells of the Berettyóúfalu Baths that serves three functions: geothermal heating, bathing water for the pools, as well as medical purposes at the Rehabilitation Department of the neighbouring Gróf Tisza István Hospital. Two percent is covered by joint operation for bathing and agricultural purposes, while $\mathrm{s} \%$ falls on combined bathing and industrial, as well as bathing and communal water supply utilization. Agricultural utilization is still significant within the use of thermal water in Hajdú-Bihar County with $9 \%$, similarly to communal water use with Io\%. In spite of their theoretical importance, no geothermal systems for the individual settlements - like the ones in Kistelek or Mórahalom - have been constructed, as today there is not a single local government where planning would have been followed by actual implementation. Investments are hindered by the general shortage of resources at the local governments, which situation is not expected to change even on the medium term with respect to the increasingly more frequent municipal bankruptcies (Fig. 7-IO).

Within the fields of the use of the water exploited from the thermal water wells of JászNagykun-Szolnok County, the supply of mains water from thermal water wells has gained outstanding significance in comparison with the two other counties - in the county it has a $38 \%$ share from overall utilization. Utilization for medical purposes is implemented in the hospitals of Mezőtúr and Karcag; in this latter institution, thermal water is used jointly with the neighbouring bathing establishment. Thermal water has been used on several occasions as a geothermal energy carrier, especially to supply heating and sanitary hot water to the military establishments of Szandaszőlős, as well as to heat 


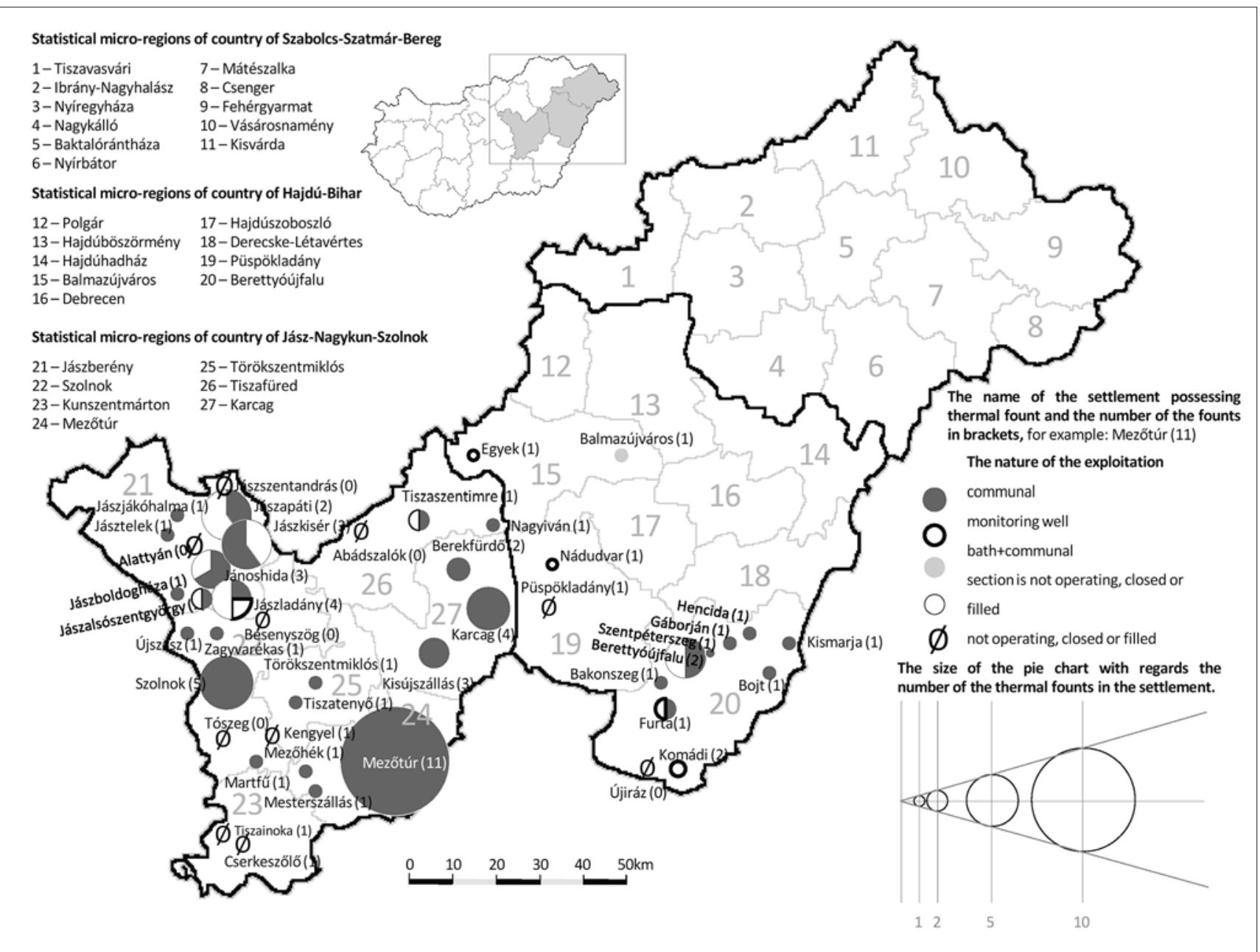

Figure 8. Thermal wells serving communal water supply in 2011 [Source: collected by the author from owners of thermal wells]

the hospital of Szolnok. There is one thermal well that expressly serves research objectives. It is the thermal well of Jászladány, which has been constructed for the Geological Institute of Hungary (MÁFI) for the purpose of depth monitoring studies. Initially, multiphase and shared use was applied in four wells: the thermal well of Tisza Hotel in Szolnok served balneological ends and the heating of the building, two wells in Abádszalók were used for communal water supply and the filling of bathing facilities, whereas the thermal well of the hospital of Karcag had medical and water supply tasks to bathing.

In this county boasting of the best endowments, by 20 II the volume of the use of operating ther- mal water supply wells for drinking water - otherwise representing the largest number of wells - has decreased by $34.5 \%$ with one of the indirect causes being the dynamic rise of water tariffs after 1990 and the concurrent drop in the number of consumers. In spite of their outstanding number, their role in water supply is rather insignificant, a large proportion of them is out of use. The only exception is given by certain areas of Jászság, where they take a more weighty part in communal water supply. Thermal wells initially designed for medical purposes, geothermal heating, combined balneological and the heating of buildings, as well as bathing and medical purposes are mostly still in operation (Fig. 7-Io). 


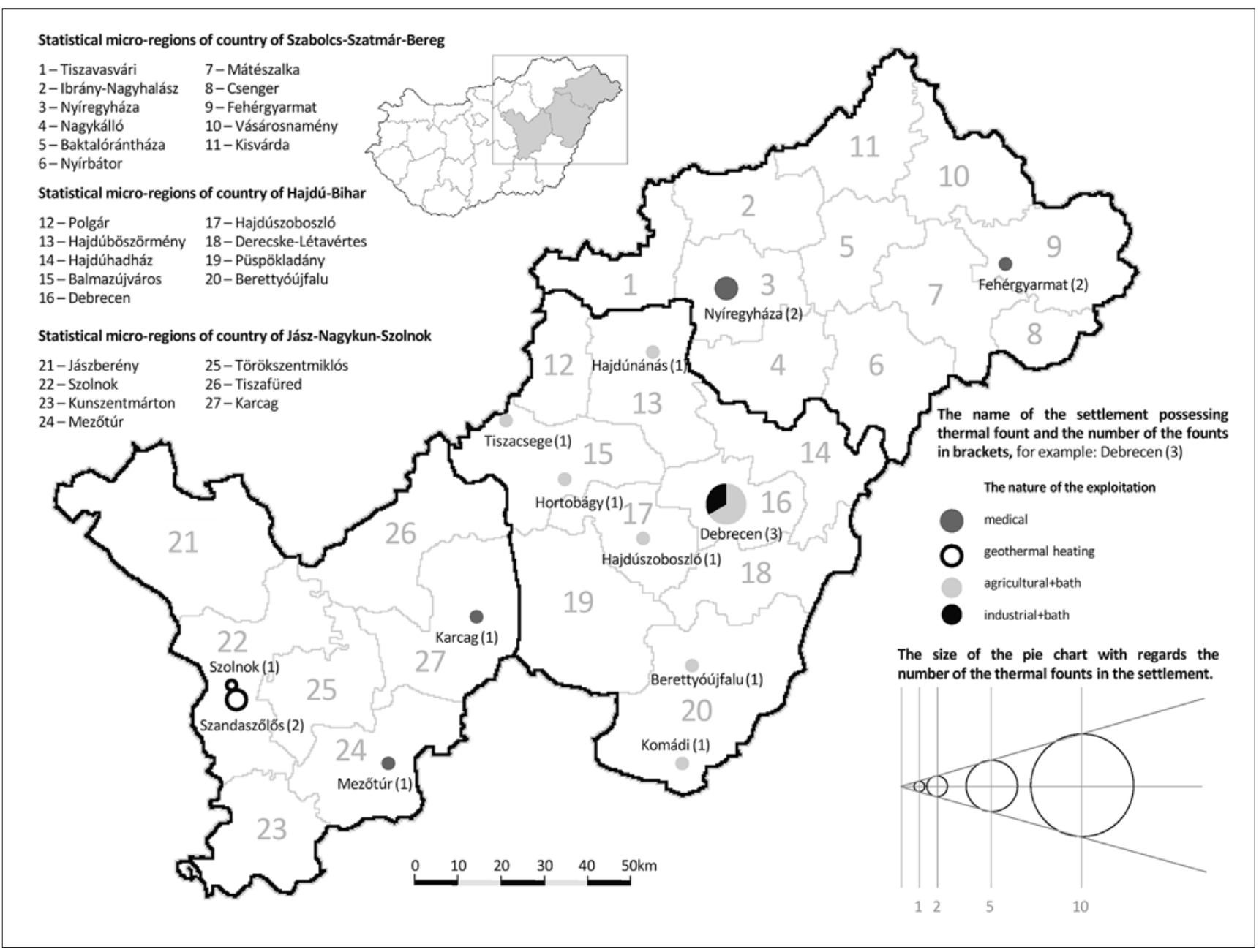

Figure 9. Geographic locations of thermal wells established to satisfy the demands of the tertiary sector, as well as for multistage utilization in the respective years of construction [Source: figure created by the author based on data of UpperTisza Region Environmental and Water Directorate, Trans Tisza Region Environmental and Water Directorate, Middle-Tisza Region Environmental and Water Directorate and the author]

\section{Conclusions}

Since 1915, the North Great Plain Region has witnessed the drilling of 305 thermal wells that have served versatile purposes of utilization from bathing to agriculture, from industry to communal water supply. With respect to the whole of the region, in terms of the number of wells the largest user is balneology with $35 \%$, followed by communal water supply with $26 \%$, agriculture with $21 \%$ and industry with 10\%. Apart from joint use for agricultural and bathing purposes, as well as monitoring and therapeutic objectives one or two examples of combined utilization and use as geothermal energy can be found in the region.

Throughout the decades, due to the changes in the economic landscape, the role taken by the government and the transformation of public administration, the number of thermal wells used has dropped by $30 \%$, the weights of utilization have shifted, the structure of use has been some- what converted. In 20II, the largest user continued to be balneology with $22 \%$, followed by communal water supply with $17 \%$ and agricultural utilization with I4\%. These sectors have preserved this rank, but similarly to the average of the region the number of wells used has dropped by nearly $30 \%$. With respect to the changes in the priorities of thermal water use, a positive process has been the growing popularity of the utilization of geothermal energy carried by thermal water as an alternative mode of energy utilization, but this type of use is characteristic of solely bathing complexes. On the average, the largest fallback has been suffered by the application of industrial thermal water, which has risen to $50 \%$ on a regional level. For therapeutic and various multistage utilization modes, there are just a few examples in the region (Figure II-I2).

In the light of the foregoing, it can be claimed that with respect to the existing capacities the 


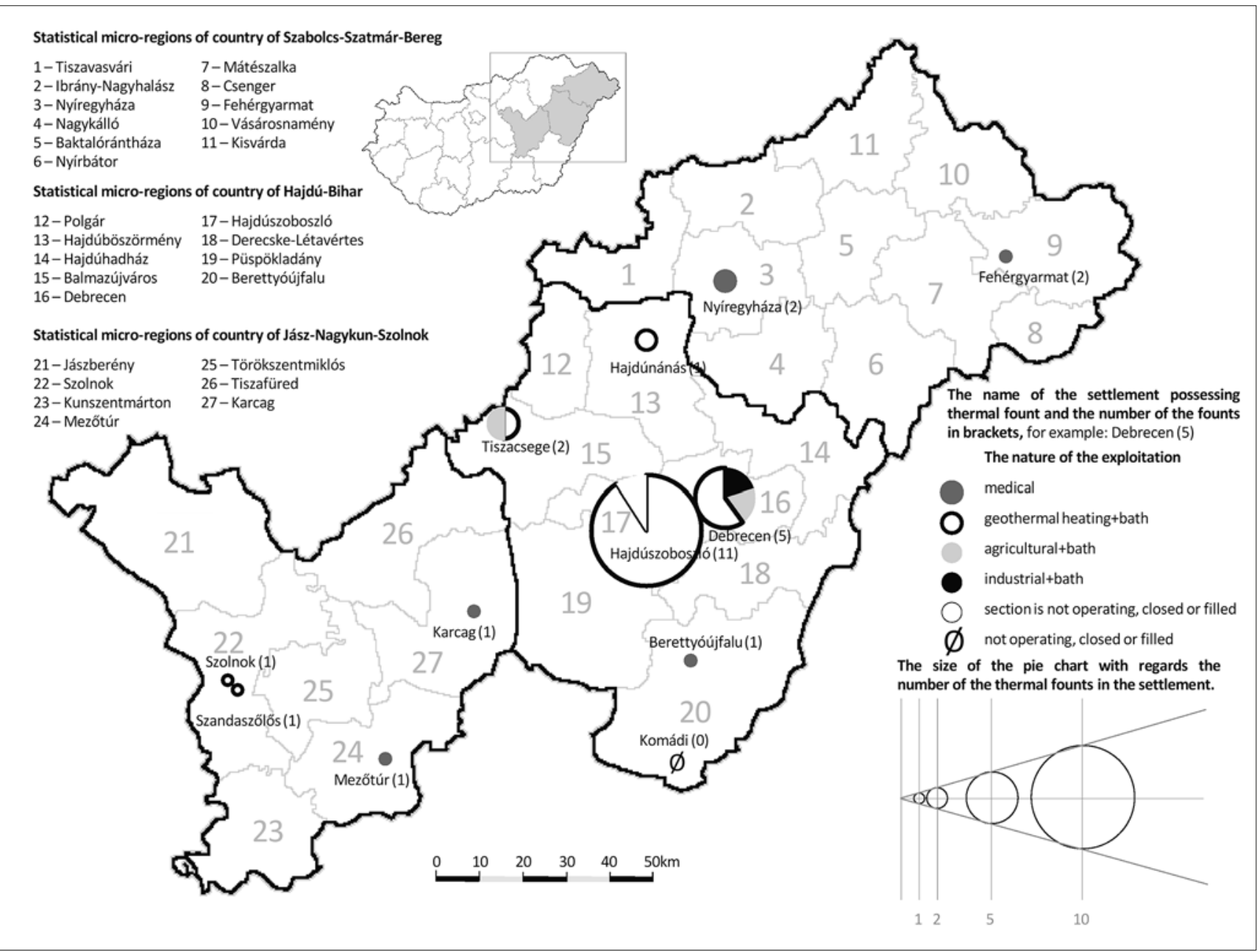

Figure 10. Thermal wells operating in the area of the tertiary sector and involved in multistage utilization, in 2011 [Source: collected by the author from owners of thermal wells]

North Great Plain Region has considerable unused thermal water and geothermal energy reserves that are present in the thermal wells currently out of operation. On the basis of the practical experience of the users and the characteristics described above, there are two areas that seem to be promising in the use of heat energy. One of them is comprised by small towns and similar settlements, where the given number of inhabitants and businesses ensures such revenues for the local governments that enable them to participate successfully in renewable energy grant applications, and where such a number of institutions are maintained whose heating demands can be covered from the available thermal water capacities.

The other area is agriculture, and in particular cooperatives and joint stock companies that have been able to preserve their farmlands, and operate extensive agricultural profiles including both plant farming and animal breeding. In the process of continuous modernization, these business entities do dedicate resources to the funding of investments based on energy-saving operations and renewable energies, as well as participation in the associated grant applications. Examples from southeastern Hungary - Pálmonostora, Fülöpjak$\mathrm{ab}$ - show that even on the level of family enterprises there are option to rely on geothermal energy, yet the given business profile should be capable of generating large added values - on the level of the produced food and industrial crops -, and realizing considerable revenues.

No further, extensive bathing developments can be regarded to be feasible, unlike the improvement of the quality of the existing capacities and their multiphase utilization, such as communal heating of households and agricultural use. As a consequence, heat trade would bring additional resources for profitable operation. 


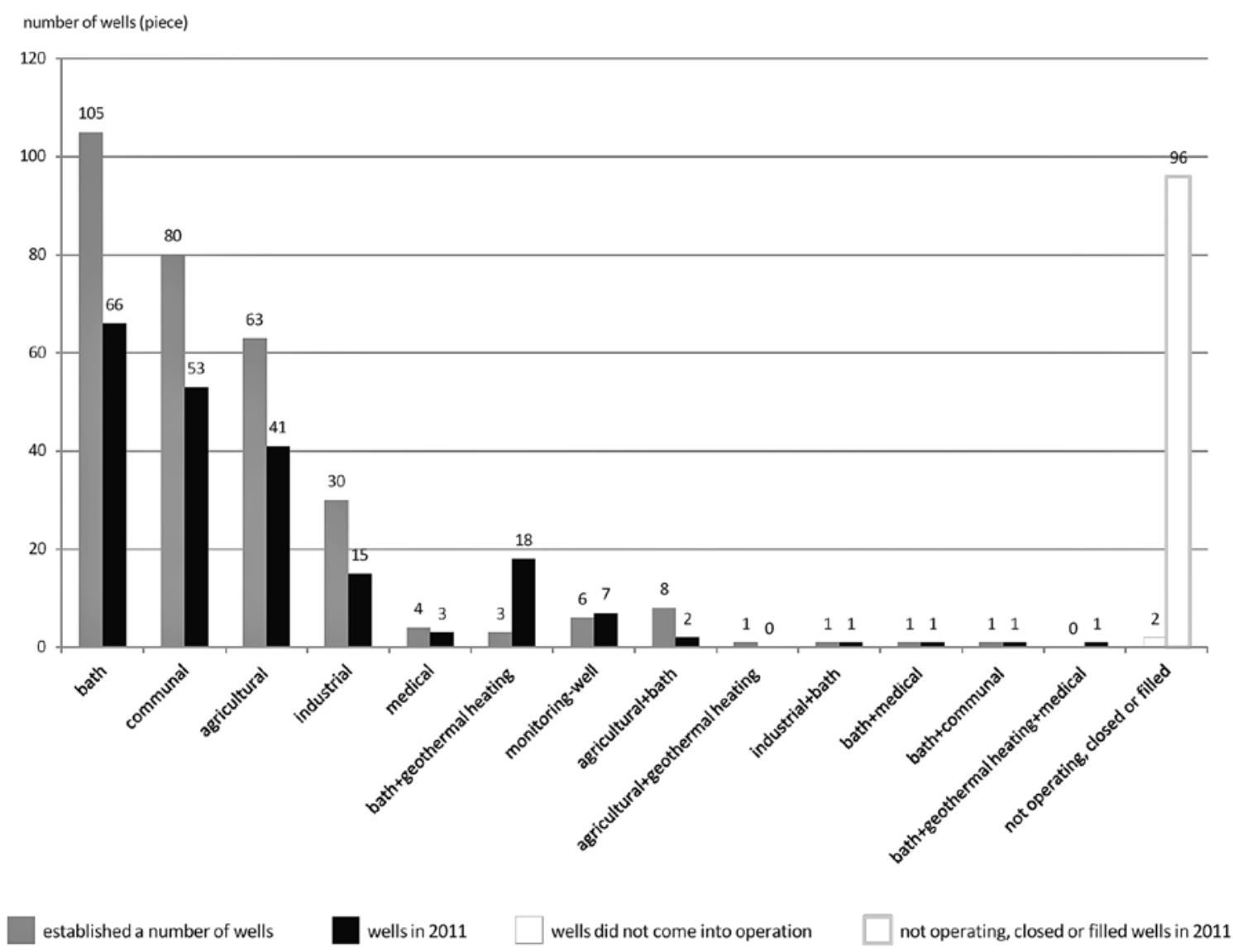

Figure 11. Distribution of the thermal wells in the North Great Plain Region among the fields of utilization and methods, in the respective years of construction and 2011 [Source: figure created by the author based on data of Upper-Tisza Region Environmental and Water Directorate, Trans Tisza Region Environmental and Water Directorate, Middle-Tisza Region Environmental and Water Directorate and the author]

\section{References}

Csomós, Gy., Kulcsár, B. 20II. Economic significance of tourism based on thermal water in the case of three small towns located in different environments. A termálvízre alapozott idegenforgalom gazdasági jelentősége három eltérő környezetben fekvő kisváros esetében. Debreceni Szemle 20II/4. pp. 406-4I4.

Dövényi, P., Drahos, D., Lenkey, L. 20or. Mapping of Hungary's geothermal energy potential regarding consumption enhancement. Conditions of temperature. Magyarország geotermikus energia-potenciáljának feltérképezése a felhasználás növelése érdekében. Hőmérsékleti viszonyok. Jelentés a Környezetvédelmi Alap Célelőirányzat részére. ELTE, Geofizikai Tanszék, I-Io.

Lorberer, Á. 2003. Hydrogeological bases and water recources management status assessment of thermalwater utilization of domestic agricultural. A hazai mezőgazdasági hévízhasznosítás hidrogeológiai alapjai és vázlatos vízkész- let-gazdálkodási állapot-értékelése. VITUKI, Budapest, 54 .

Lorberer, Á. 2009. Thermal wells of thermalbaths in the eastern part of the Trans Tisza Region. Termálfürdők hévízkútjai a Tiszántúl K-i részén. VITUKI, Budapest. I-9.

Mádlné Szőnyi, J. 20o8. International and domestic state of geothermal energy utilization, prospects in Hungary. A geotermikus energiahasznosítás nemzetközi és hazai helyzete, jövőbeni lehetőségei Magyarországon, MTA, Budapest, I-IO5.

Molnár, B. 1984. Evolution of the Earth and life. A Föld és az élet fejlődése, Nemzeti Tankönyvkiadó, Szeged, I-35I.

Royden, L.H., Dövényi P. I988. Variations in extensional styles at depth across the Pannonian basin system. In: Royden L. H. \& Horváth F. (eds.): The Pannonian Basin, a Study in Basin Evolution. American Association of Petroleum Geologists Memoirs, 45, 235-255. 


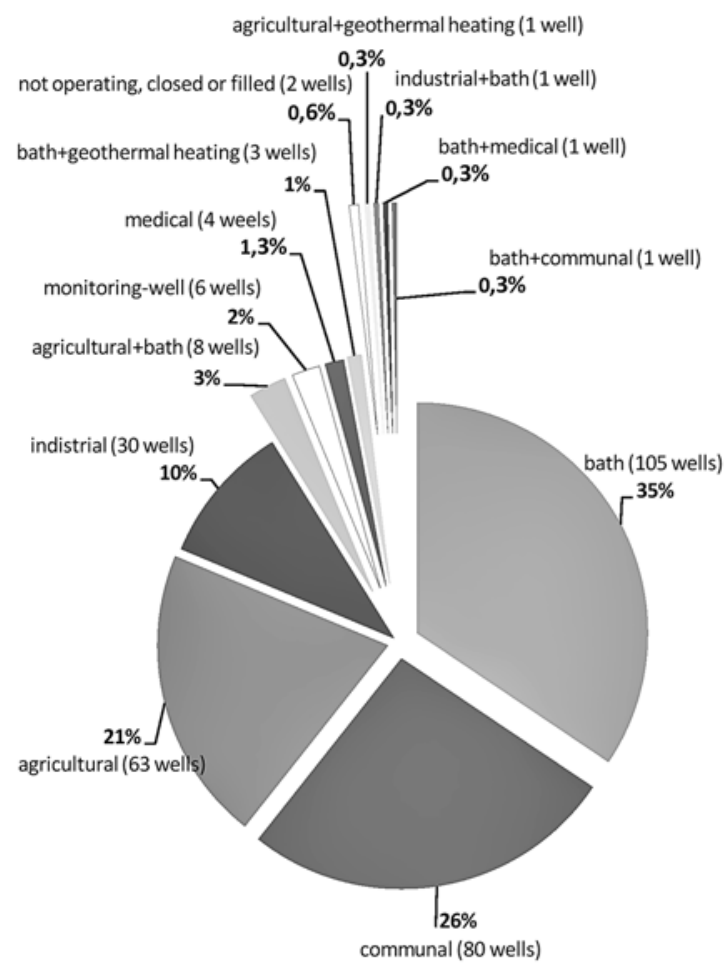

ESTABLISHMENT

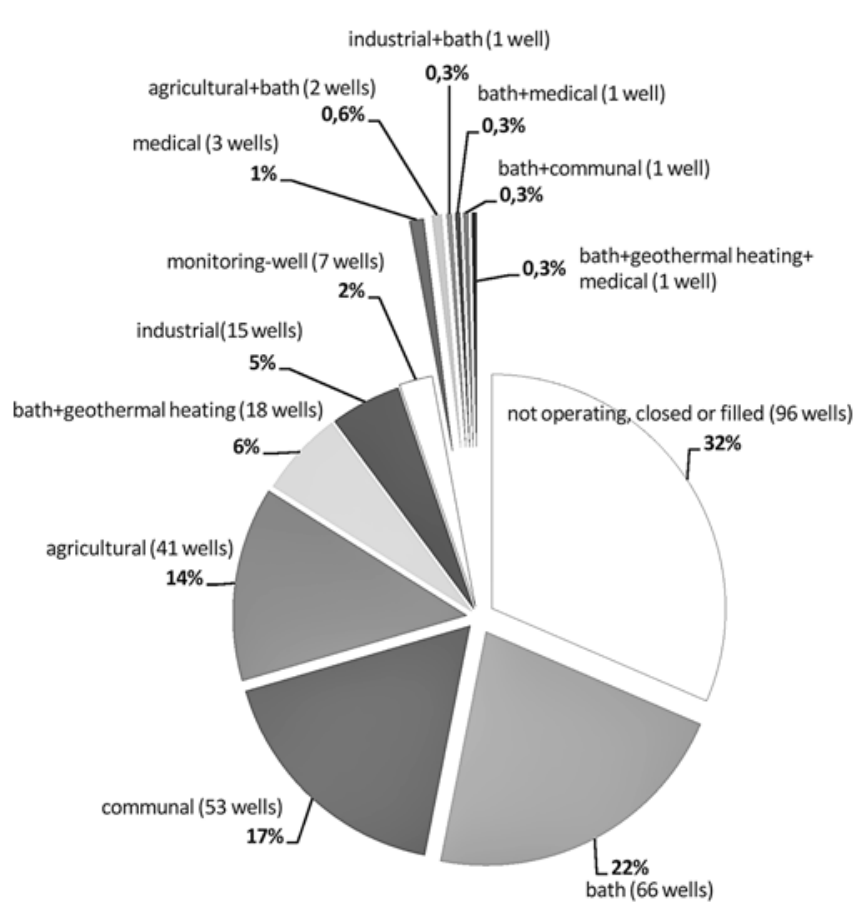

IN 2011

Figure 12. Utilization of thermal wells in the North Great Plain Region, in view of the fields of utilization and methods, in the respective years of construction and 2011 [Source: figure created by the author based on data of Upper-Tisza Region Environmental and Water Directorate, Trans Tisza Region Environmental and Water Directorate, Middle-Tisza Region Environmental and Water Directorate and the author]

Royden, L.H., Horváth F., Nagymarosy A., Stegena L. I983. Evolution of the Pannonian basin system: 2. Subsidence and thermal history. - Tectonics, 2, 9I-I37.

Stegena L., Géczy B., Horváth F. I975. Late Cenozoic evolution of the Pannonian basin. - Tectonophysics, 26, 7I-90.

Hungary's Renewable Energy Utilization Action Plan 2010-2020, Ministry of National Development, Magyarország megújuló energia hasznosítási cselekvési terve 2010-2020, Nemzeti Fejlesztési Minisztérium, 2009.

Data source: Middle-Tisza Region Environmental and Water Directorate, (Közép-Tisza-vidéki Környezetvédelmi és Vízügyi Igazgatóság KÖTIKÖVIZIG), 2009, Szolnok.

Data source: Trans Tisza Region Environmental and Water Directorate, (Tiszántúli Környezetvédelmi és Vízügyi Igazgatóság - TIKÖVIZIG), 2009, Debrecen.

Data source: Upper-Tisza Region Environmental and Water Directorate, (Felső-Tisza-vidéki
Környezetvédelmi és Vízügyi Igazgatóság - FETIKÖVIZIG) 2009, Nyíregyháza.

59/2008. (IV. 29.) Ministry of Agriculture and Rural Development decision on „detailed rules of action plan needed to protect water against agricultural nitrate contamination and order about supplying data and registration."; 59/2008. (IV. 29.) FVM rendelet „a vizek mezőgazdasági eredetű nitrátszennyezéssel szembeni védelméhez szükséges cselekvési program részletes szabályairól, valamint az adatszolgáltatás és nyilvántartás rendjéről”.

27/2007. (IV. I7.) Ministry of Agriculture and Rural Development decision on „Detailed conditions of subsidies granted to the modernization of animal keeping estates from the European Agricultural Fund for Rural Development"; 27/2007. (IV. I7.) FVM rendelet „az Európai Mezőgazdasági Vidékfejlesztési Alapból az állattartó telepek korszerüsítéséhez nyújtandó támogatások részletes feltételeiről”. 